Jurnal Teknologi Laboratorium

Vol.8, No.2, September 2019, pp. $64-69$

ISSN 2580-0191 (Online), ISSN 2338 - 5634 (Print)

DOI: 10.29238/teknolabjournal.v8i2.177

Journal homepage: https://www.teknolabjournal.com/index.php/Jt//index

\title{
The potency of bay leaves extract (Syzygiumpolyanthum) as anti-inflammation in Rattus norvegicus induced with Complete Freund's Adjuvant
}

\author{
Dwi Candra Buana ${ }^{1 a^{*}}$, I Ketut Sudiana ${ }^{2 b}$, Jusak Nugraha ${ }^{3 c}$ \\ ${ }^{1}$ Post Graduates School of Immunology, Universitas Airlangga, Surabaya, Indonesia \\ ${ }^{2}$ Department of Clinical Anatomy, Faculty of Medicine, Universitas Airlangga, Surabaya, Indonesia \\ ${ }^{3}$ Department of Clinical Pathology, Dr. Sutomo General Academic Hospital, Surabaya, Indonesia \\ a Email address: an dra2112@yahoo.com \\ ${ }^{\mathrm{b}}$ Email address:ik.sudiana@yahoo.com \\ cEmail address: jusak.nugraha@yahoo.com
}

\section{HIGHLIGHTS}

Bay leaves extract (Syzygiumpolyanthum) can prevent inflammation in rat (Rattus norvegicus) induced with Complete Freund's Adjuvant (CFA)

\section{ARTICLE INFO}

\section{Article history}

Received Date: July $12^{\text {nd }}, 2019$

Revised Date: September $18^{\text {th }}, 2019$

Accepted Date: September $27^{\text {th }}, 2019$

\section{Keywords:}

Bay leaves extract

Anti-inflammation

Complete Freund's Adjuvant

Arthritis

\section{A B S T R A C T}

The using of herbal plants in Indonesia as medicine based on traditional knowledge. One of the herbal plants that believed has medication effect is bay leaves (Syzygiumpolyanthum). Bay leaves contain a flavonoid that can prevent inflammation. The study aims to prove the potency of bay leaves extract to prevent the inflammation, which is indicated by decreasing the paw edema thickness in rat induced with Complete Freund's Adjuvant (CFA). This study used 25 animal models of male rat (Rattus norvegicus) strain Wistar that divided into five groups, one group for a normal group (no treatment), one group for positive control which was injected with CFA sub plantar and given treatment with $\mathrm{Na} \mathrm{CMC}$ and three test groups which is got three different doses of bay leaves extract peroral and the doses were $100 \mathrm{mg} / \mathrm{kg} \mathrm{BW}, 300 \mathrm{mg} / \mathrm{kg} \mathrm{BW}, 400 \mathrm{mg} / \mathrm{kg} \mathrm{BW}$, and injected with CFA into the sub plantar. Bay leaves extract was given one hour per oral before injected with CFA. The measurement of paw edema was done at 24 hours after CFA injection. The result of this study showed that bay leaves extract gave the anti-inflammation effect to the rats which were injected with CFA. It is concluded that bay leaves extract containing flavonoid plays a role in inhibit cytokines proinflammatory synthesis.

\section{${ }^{*}$ Corresponding Author:}

I Ketut Sudiana

Department of Clinical Anatomy, Faculty of Medicine, Universitas Airlangga,

Jl. Mayjend Prof.Dr.Moestopo No.47,Kec.Tambaksari,Surabaya 60132

Email: ik.sudiana@yahoo.com 


\section{INTRODUCTION}

Inflammation is a response of the host to protect itself from infection and tissue damage which involve of immune cells and gathering of plasma protein to the area of infection and tissue damages by removing the injurious stimuli as well as initiate the healing process for the tissue and also vasodilatation of blood vessels. ${ }^{1,2}$ Inflammatory process involves a series of phenomena that can be triggered by various stimuli such as infectious agents, ischemia, antigen-antibody interactions and thermal or injury caused by other physical agents. ${ }^{3}$ This series of events leads to the release of damage-associated molecular patterns (DAMPs) then stimulate TLRs on macrophage inducing upregulation of cytokines TNF- $\alpha$ and IL-1 $\beta$ by way of NFKB activation. ${ }^{4}$ The inflammation is characterized with five cardinal signs namely redness, swelling, heat, pain, and loss of function. $\frac{5}{}$

Bay leaves is mostly distributed in the tropic and subtropic area especially in Southeast Asia including Indonesia and Malaysia. ${ }^{-}$Bay leaves usually use as a traditional medication for treating diabetes mellitus, hyperuricemia, hyper cholesterol, gastritis, hypertension, diarrhea and rheumatism. ${ }^{7}$ Bay leaves contain of tannin, flavonoid, alkaloid and essential oil whereas flavonoid has an active role as anti-inflammation by inhibiting of transcription factors such as NF-kB.,,$\underline{9}$ Previous study showed that bay leaves extract with concentration $200 \%$ could reduce the inflammation to the rats that were dipped with phenol 50\%. ${ }^{10}$ Flavonoid based the chemical features are divided into subclasses: flavonols, flavones, flavanones, flavanols, anthocyanins, isoflavones, chalcones and dihydrochalcones. 11

Complete Freund's Adjuvant (CFA) is a mixture of paraffin oil and surfactant with heat-killed Mycobacterium tuberculosis or $M$. butryicum in which aqueous antigen solutions are emulsified. $\frac{12}{12}$ CFA has been used to induce inflammation and study inflammatory pain in several animal models, and it attempts to mimic human conditions of persistent or chronic inflammatory pain. Role of CFA is concluded that adjuvant activity from sustain release of antigens from the oily deposit and stimulation of local innate immune response causing delayed hypersensitivity reaction that can react with intense inflammatory reaction and hyperalgesia at the site of injection. $\frac{13}{2}$ Therefore, this study aimed to prove the potency of bay leaves extract to prevent the inflammation, which is indicated by decreasing the paw edema thickness in rats induced with CFA.

\section{MATERIALS AND METHOD}

This study used adult male Wistar rats aged 12 weeks, weighing 200-250 gram, were acclimated one week before the experiment in a room with constant temperature $\left(25-26{ }^{\circ} \mathrm{C}\right)$. Food and water were available ad libithum, and all the procedure were approved by Biochemical Laboratory of Medicine Faculty of Universitas Airlangga. This study was approved by the Ethical Committee of Dental Medicine Faculty, Universitas Airlangga 066/HRECC.FODM/II/2019. The data were analyzed by calculating mean and standard deviation.

Bay leaves derived and determined from Material Medika, Batu, Indonesia. Phytochemical screening test for bay leaves included was standardized of flavonoid. Stages to be performed were following: $500 \mathrm{~g}$ powder of bay leaves is macerated with $3 \mathrm{~L}$ of ethanol $70 \%$ for 24 hours, after maceration by mixing the processed bay leaves into rotary evaporator for 90 minutes ( 3 hours) then we get $370 \mathrm{~mL}$ of solution then added $8 \%$ of amylum (29.6 gram) then we get 50 grams dry extract of bay leaves. From the extract has done Phytochemical screening to know the presence of flavonoid in this extract given.

The Phytochemical screening was performed through Shinoda's test. The one mg bay leaf extract is added with $0.5 \mathrm{~mL}$ of hydrochloric acid and magnesium metal, and then reddish colouration appeared to confirm the presence of flavonoid. Inflammation model in this study used CFA (Invivogen) $0.1 \mathrm{~mL}$ mixed with phosphate buffer saline (PBS) $0.1 \mathrm{~mL}$. This solution was injected into right hind paw sub plantar. Animals were then divided into five groups ( $n=5 /$ group) named normal group/ no treatment (Kn), CFA-control group (Kk), CFA with peroral prevention of bay leaves extract group (Kp1, Kp2, Kp3) with dose $100 \mathrm{mg} / \mathrm{kg} \mathrm{BW,} 300 \mathrm{mg} / \mathrm{kg}$ BW and $400 \mathrm{mg} / \mathrm{kg} \mathrm{BW}$. The bay leaves extract was given per oral one hour before CFA induction. The measurement of hind paw edema used digital calliper at 24 hours after CFA injection.

The mean of group kn recorded lowest amongst all because of no experimental method was applied. Group Kk with CFA injected and Kp1 with $100 \mathrm{mg} / \mathrm{kg} \mathrm{BW}$ mean is higher as compared to others with CFA and bay leaf higher dose i.e. $\geq 100 \mathrm{mg} / \mathrm{kg} \mathrm{BW}$ subsequently we have to increase to dose to achieve the results. Consequently, dose increased to 300 and $400 \mathrm{mg} / \mathrm{kg} \mathrm{BW}$ hence the 
mean of group kp2 and kp3 are decreased. We can still evaluate the higher dose, i.e. $\geq 400 \mathrm{mg} / \mathrm{kg}$ $\mathrm{BW}$, to achieve the maximum results. The dose $400 \mathrm{mg} / \mathrm{kg} \mathrm{BW}$ is effective to inhibit the inflammation as compare to other compered groups in the study hence a future study is recommended to prolong the treatment and duration to observe the effects. We also applied Levene's test for homogeneity, i.e. one-way ANOVA in table 2. There is a difference between the control group and treatment groups, because of non-homogeneity of data, we used Tamhane posthoc multiple comparisons. Tahmane test results show that CFA applied to group and treatment with dose $400 \mathrm{mg} / \mathrm{kg}$ BW has a significant effect determined by $p$-value, which is $p \leq 0.05$. Hence it can be concluded that there is a difference between the control group with treatment group having applied dose of $400 \mathrm{mg} / \mathrm{kg} \mathrm{BW}$.

\section{RESULTS AND DISCUSSION}

There are many studies discussing the inflammation and flavonoids $\frac{14}{}$ and bay leaf and flavonoids $\frac{15}{}$ and its role in diseases. $\frac{16}{-}$ The role of flavonoids and how to decrease inflammation by using it is discussed in details by Levya-Lopez. . $^{17}$ According to Levya-Lopez ${ }^{17}$ flavonoid can function in propelling the activation of NFkB so the synthesis of pro-inflammation cytokine, i.e. TNF- $\alpha$ can be inhibited. The flavonoids are also correlated with the structure-activity and have the ability to inhibit neutrophil degranulation. ${ }^{2}$ Hence, we can assume that through neutrophil degranulation, we can identify inflammation easily. In view of discussion and explanation by Rathee ${ }^{2}$ we can thus, assume that the current study hypotheses the functions of bay leaves as the anti-inflammation agent.

The measurement of hind paw edema thickness used a digital calliper and was done at 24 hours after CFA injection because subcutaneous injection in right hind paw of CFA induces a more prolonged swelling that becomes maximal at 24 hours and persists for at least seven days. $\underline{18,19}$

Table 1. Hind Paw Edema Thickness (in $\mathrm{mm}$ )

\begin{tabular}{|c|c|c|c|c|}
\hline & \multirow{2}{*}{$\begin{array}{c}\text { Minimum } \\
\text { Statistic }\end{array}$} & \multirow{2}{*}{$\begin{array}{c}\text { Maximum } \\
\text { Statistic }\end{array}$} & \multicolumn{2}{|c|}{ Mean } \\
\hline & & & Statistic & Std. Error \\
\hline $\mathrm{kn}$ & 2.25 & 2.28 & 2.2620 & 0.00583 \\
\hline kk & 5.49 & 5.70 & 5.5880 & 0.03904 \\
\hline kp1 & 4.69 & 6.01 & 5.3680 & 0.20958 \\
\hline kp2 & 3.71 & 5.42 & 4.9300 & 0.31056 \\
\hline kp3 & 4.48 & 4.94 & 4.7460 & 0.10127 \\
\hline
\end{tabular}

Noted: $\overline{\mathrm{Kn}}={ }^{(\text {Normal) })} \mathrm{kK}={ }^{(\text {CFA Injected) })} \mathrm{kp} 1={ }^{(\text {treatment with } 100 \mathrm{mg} / \mathrm{kgBW})} ; \mathrm{kp}{ }^{(\text {treatment with } 300 \mathrm{mg} / \mathrm{kgBW})} ; \mathrm{kp} 3^{\text {(treatment with } 400 \mathrm{mg} / \mathrm{kgBW})}$

From the Table 1 showed that the mean of each treatment group showed that all variances dose of bay leaves extract has the capability to inhibit the inflammation than a group of CFA with no treatment (Kk) and a group of kp3 showed the lowest mean than the other treatment groups.

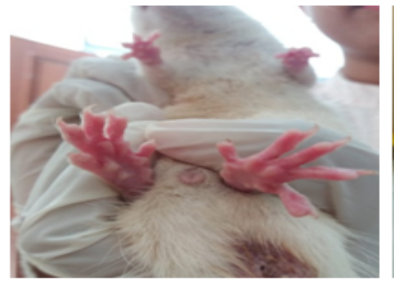

Figure A

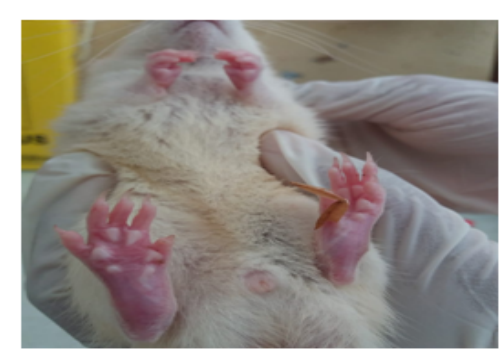

Figure D

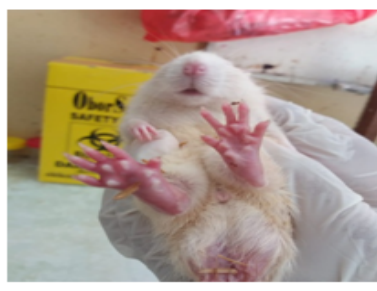

Figure B

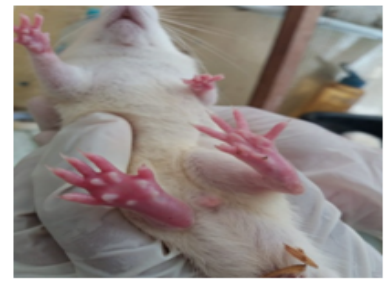

Figure C
Figure 1. Hind paw edema of Wistar rats after 24 hours CFA induction 
Noted:

Figure A: Hind paw of a normal rat with no treatment $(\mathrm{Kn})$.

Figure B: Hind paw edema of rat with $\mathrm{CMC} \mathrm{Na}$ and CFA induction (Kk).

Figure C: Hind paw edema of rat with bay leave extract with dose $100 \mathrm{mg} / \mathrm{kg} \mathrm{BW}$ and CFA induction (Kp1).

Figure D: Hind paw edema of rat with bay leave extract with dose $300 \mathrm{mg} / \mathrm{kg} \mathrm{BW}(\mathrm{Kp} 2)$.

Figure E: Hind paw edema of rat with bay leave extract with dose $400 \mathrm{mg} / \mathrm{kg} \mathrm{BW}$ (Kp3).

From figure 1 showed the inflammation of right hind paw on each group, from figure $E$ showed less inflammation after 24 hours of CFA induction, it means that dose $400 \mathrm{mg} / \mathrm{kg} \mathrm{BW}$ has a possibility to inhibit the inflammation than no treatment group (kp3)

\section{Mean of paw edema thickness}

(in $\mathrm{mm}$ )

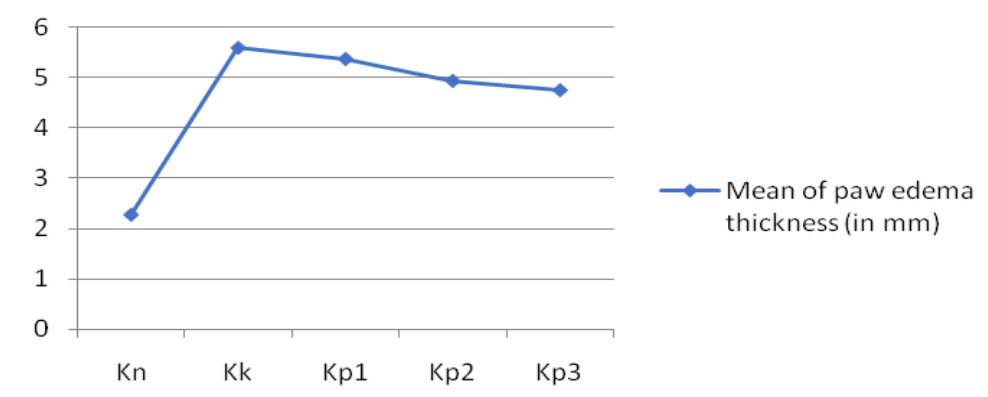

Figure 2. Graphic decreasing of paw edema thickness after 24 hours CFA injection

From figure 2 showed that there is increasing of mean value from Kn group to Kk group, but it also shows that there is decreasing of mean value from $\mathrm{Kk}$ group and all variances dose of treatments and Kp3 group shows the lowest mean value than the other treatment groups.

Table 2. Test of Homogeneity of Variances (for treatment)

\begin{tabular}{cccc} 
Levene Statistic & df1 & df2 & Sig. \\
\hline 2.954 & 4 & 20 & 0.045 \\
\hline
\end{tabular}

The table 2 is explaining homogeneity of variance for treatment through Levene's, and the result shows that there is no homogeneity noted in these groups. Thus, data was not homogeneous; we keep using posthoc multiple comparisons using Tamhane.

Table 3. ANOVA (Treatment)

\begin{tabular}{cccccc}
\hline & Sum of & Mean & Sig. \\
\hline Squares & df & Square & F & Siween \\
Groups & 35.801 & 4 & 8.950 & 58,810 & 0.000 \\
Within Groups & 3.044 & 20 & 0.152 & & \\
Total & 38.845 & 24 & & & \\
\hline
\end{tabular}

To see the difference between the group, we applied the One-Way ANOVA test, it shows the value of $p<0.05$ indicates the significance of the current study, from table 3 shows that between the CFA applied to group and treatment $400 \mathrm{mg} / \mathrm{kg} \mathrm{BW}$ is significant with a value of $p=0.005(p<0.05)$, so that means it has a difference between the control group and the treatment group $400 \mathrm{mg} / \mathrm{kg} \mathrm{BW}$, from the result based on table 4 using Tamhane Post Hoc Multiple Comparison shows that there was difference result on each group of treatment with bay leaves extract (Kp1, Kp2, Kp3) compared with the CFA group (Kk) and the group of Kp3 showed the stronger inhibitory activity against inflammatory paw edema with value of $p=0,005(p<0,05)$. It means that dose $400 \mathrm{mg} / \mathrm{kg}$ BW is an effective dose to inhibit the inflammation as compare to other compered groups in the study. 
Table 4. Post Hoc Multiple Comparison

\begin{tabular}{ccc}
\hline Tamhane & Sig \\
\hline Kk & Kn & 0.000 \\
& Kp1 & 0.988 \\
Kp2 & 0.656 \\
& Kp3 & 0.005 \\
\hline
\end{tabular}

CFA consist of mineral oil, containing a suspension of whole or pulverized heat-killed mycobacteria and its adjuvant activity results from the sustained release of antigens from the oily deposit and stimulation of a local innate immune response causing a delayed hyper-sensitivity reaction with an intense inflammatory reaction at the side of injection. $\frac{13}{}$ A previous study showed that sub-plantar injection of CFA resulted in a significant elevation in IL-1B as a proinflammatory cytokine.$^{20}$ The paw edema thickness of treatment group (Kp1, Kp2, Kp3) when compared to normal group (Kn) still have big difference in value (figure 1) because subcutaneous injection of CFA induced inflammation is still in the acute phase ( $0-10$ days) is caused by various mediators such as histamine, serotonin, kinins and prostaglandins, released by leukocytes that migrate to the affected region and provoked a vasculo-exsudatif phenomena responsible edema. ${ }^{21}$ When CFA was injected subplantar into paw, then it will make DAMPs forming to the protein of cell and cytoplasm. One of the receptor that binding to DAMPs is a toll-like receptor (TLR) then the inflammation cells which is inside the cytosol will activate MyD-88 then MyD-88 will activate TRAF-6 then TRAF- 6 will activate IRAK-1 and IRAK-4, these 2 part will activate NFKB then NFKB will translocate to the cell nucleus to induce DNA to synthesize proinflammation cytokines like TNF- $\alpha$ and IL-1 $\beta . .22$

The anti-inflammation action of bay leaves extract might be related to flavonoid as antiinflammation. The activity of flavonoid in the inflammatory response include the inhibition of

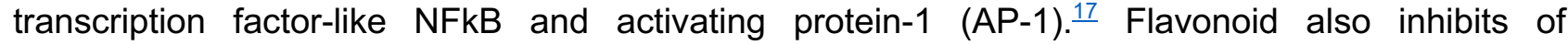
cyclooxygenase (COX) which has an important role as inflammatory mediator and is involved in the release of arachidonic acid that could be affected of starting point for general inflammatory response because it is a precursor for the biosynthesis of eicosanoids like prostaglandins and prostacyclin. ${ }^{2}$ When the transcription factor is inhibited then it would be affected to the synthesis of proinflammatory cytokines like TNF- $\alpha$, IL- $1 \beta$ and IL- 6 and IL- 8 and indicated with inhibiting leukocyte migration and edema formation. $,, 9, \underline{32}$

\section{CONCLUSION}

Bay leaves (Syzygiumpolyanthum) extract with dose $100 \mathrm{mg} / \mathrm{kg}, 300 \mathrm{mg} / \mathrm{kg} \mathrm{BW}$ and 400 $\mathrm{mg} / \mathrm{kg} \mathrm{BW}$ were applied and found $400 \mathrm{mg} / \mathrm{kg} \mathrm{BW}$ effective in preventing inflammation in rats with induced CFA. Bay leaves extract contains flavonoid that may inhibit NFKB, which has important role in cytokines proinflammatory synthesis like TNF- $\alpha$ dan IL-1 $\beta$.

\section{ACKNOWLEDGEMENT}

We thank to all the staff at Biochemistry Laboratory Faculty of Medicine, Universitas Airlangga, Surabaya, Indonesia.

\section{CONFLICT OF INTEREST}

We declared in this work, not any conflict of interest.

\section{REFERENCE}

1. Liu T, Zhang L, Joo D, Sun S-C. NF-KB signaling in inflammation. Signal transduction targeted therapy. 2017;2(1):1-9.

2. Rathee $P$, Chaudhary $H$, Rathee S, Rathee D, Kumar V, Kohli K. Mechanism of action of flavonoids as anti-inflammatory agents: a review. Inflammation allergy-drug targets. 2009;8(3):229-235.

3. Purohit KSaD. Therapeutic Effect Of Flavonoids As Anti-Inflammatory Agents. World Journal Of Pharmacy And Pharmaceutical Sciences. 2016;5(12):532-543. 
4. Kandahari AM, Yang X, Dighe AS, Pan D, Cui Q. Recognition of immune response for the early diagnosis and treatment of osteoarthritis. Journal of immunology research. 2015.

5. $\quad$ Punchard NA, Whelan CJ, Adcock I. The journal of inflammation. In: BioMed Central; 2004.

6. Silalahi M. Syzygium polyanthum (Wight) Walp. Jurnal Dinamika Pendidikan. 2017;10(1):116.

7. Rahim ENAA, Ismail A, Omar MN, Rahmat UN, Ahmad WANW. GC-MS analysis of phytochemical compounds in Syzygium polyanthum leaves extracted using ultrasoundassisted method. Pharmacognosy Journal. 2018;10(1).

8. Restusari L, Arifin H, Dachriyanus YY. Pengaruh Fraksi Air Ekstrak Etanol Daun Salam (Syzygium polyanthum Wight.) Terhadap kadar asam urat darah pada tikus putih jantan hiperurisemia-diabetes. Prosiding Seminar Nasional dan Workshop "Perkembangan Terkini Sains Farmasi dan Klinik IV"2014:299-309.

9. Serafini M, Peluso I, Raguzzini A. Flavonoids as anti-inflammatory agents. Proceedings of the Nutrition Society. 2010;69(3):273-278.

10. Wientarsih I, Iskandar M, Saputra GH. The Effect of Bay Leaves Infusum (Syzygium polyanthum (Wight)) on anti inflammation in White Rat Sprague-Dawley. Paper presented at: Proceding of the Mini Workshop Southeast Asia Germany Alumni Network (SEAG)" Empowering of Society Through the Animal Health and Production Activities with the Appreciation to the Indigenous Knowledge": May 3rd-5, 2007, Manado-Indonesia2008.

11. Spagnuolo C, Moccia S, Russo GL. Anti-inflammatory effects of flavonoids in neurodegenerative disorders. European Journal of Medicinal Chemistry. 2018;153:105-115.

12. Coffman RL, Sher A, Seder RA. Vaccine adjuvants: putting innate immunity to work. Immunity. 2010;33(4):492-503.

13. Navarro-Alvarez N, Gonçalves BM, Andrews AR, Sachs DH, Huang CA. A CFA-induced model of inflammatory skin disease in miniature swine. International journal of inflammation. 2018:1-8.

14. Benavente-Garcia O, Castillo J. Update on uses and properties of citrus flavonoids: new findings in anticancer, cardiovascular, and anti-inflammatory activity. Journal of agricultural food chemistry. 2008;56(15):6185-6205.

15. Sumono A, Sd AW. The use of bay leaf (Eugenia polyantha Wight) in dentistry. Dental Journal. 2008;41(3):147-150.

16. Pan M-H, Lai C-S, Ho C-T. Anti-inflammatory activity of natural dietary flavonoids. Food function. 2010;1(1):15-31.

17. Leyva-López N, Gutierrez-Grijalva EP, Ambriz-Perez DL, Heredia JB. Flavonoids as cytokine modulators: a possible therapy for inflammation-related diseases. International journal of molecular sciences. 2016;17(6):921.

18. Fehrenbacher JC, Vasko MR, Duarte DB. Models of inflammation: carrageenan-or complete freund's adjuvant (CFA)-induced edema and hypersensitivity in the rat. Current protocols in pharmacology. 2012;56(1):5.4. 1-5.4. 4.

19. Nagarkar B, Jagtap S. Effect of new polyherbal formulations DF1911, DF2112 and DF2813 on CFA induced inflammation in rat model. BMC complementary alternative medicine. 2017;17(1):194.

20. Li M, Shi J, TANG Jr, et al. Effects of complete Freund's adjuvant on immunohistochemical distribution of IL-1 $\beta$ and IL-1R I in neurons and glia cells of dorsal root ganglion 1. Acta pharmacologica Sinica. 2005;26(2):192-198.

21. Tatiya AU, Saluja AK, Kalaskar MG, Surana SJ, Patil PH. Evaluation of analgesic and antiinflammatory activity of Bridelia retusa (Spreng) bark. Journal of traditional complementary medicine. 2017;7(4):441-451.

22. Sudiana IK. Hantaran Sinyal Pada Proses Inflamasi. Airlangga University Press. 2017(Surabaya).

23. Hošek J, Šmejkal KJ. Flavonoids as anti-inflammatory agents. Encyclopedia of Inflammatory Diseases. 2016(Parnham, M., Ed.):Springer: New York, NY, USA. 